\title{
Pepsinogen Measurement
}

National Cancer Institute

\section{Source}

National Cancer Institute. Pepsinogen Measurement. NCI Thesaurus. Code C100122.

The determination of the amount of pepsinogen present in a sample. 